\title{
Pengembalian Kerugian Negara Melalui Pembayaran Uang Pengganti
}

\author{
Sintia Febriani, Sahuri Lasmadi \\ Fakultas Hukum, Universitas Jambi \\ Author's Email Correspondence: sintiaferb@gmail.com
}

\begin{abstract}
ABSTRAK
Penelitian ini bertujuan untuk menganalisis mekanisme pengembalian kerugian negara yang diakibatkan oleh tindak pidana korupsi melalui pembayaran uang pengganti. Tipe penelitian ini adalah penelitian normatif. Hasil penelitian menunjukkan: Undang-Undang Nomor 31 Tahun 1999 Tentang Pemberantasan Tindak Pidana Korupsi sebagaimana telah diubah dengan Undang-Undang Nomor 20 Tahun 2001 Tentang Perubahan Atas Undang-Undang Nomor 31 Tahun 1999 Tentang Pemberantasan Tindak Pidana Korupsi tidak mengatur secara tegas mengenai pembayaran uang pengganti. Mekanisme pembayaran uang pengganti tidak diatur secara konkrit dalam undang-undang dan tidak ada aturan yang lebih jelas mengenai pidana penjara pengganti ketika terpidana tidak membayar pidana uang pengganti. Saran: Harus ada pengaturan mengenai mekanisme pembayaran uang pengganti.
\end{abstract}

\section{ARTICLE HISTORY}

Submission: 12 December 2020

Accepted: 03 February 2020

Publish: 07 February 2020

KEYWORDS: Corruption, Returns Losses, Replacement Money

\begin{abstract}
This article aims to analyze the mechanism of restoring state losses due to corruption through payment of financial compensation. This research is normative. The results show The basic ground of the failure of the mechanism of payment for financial compensation is not regulated concretely in Indonesia legal system. Law Number 31 of 1999 concerning Eradication of Corruption Crimes Jo. Law Number 20 Year 2001 does not explicitly regulate payment of financial compensation. Suggestion: there shall be regulatioan regarding the mechanism for payment of financial compensation.
\end{abstract}

\section{A. Pendahuluan}

Artikel ini membahas mengenai pengembalian kerugian negara melalui pembayaran uang pengganti dalam Tindak Pidana Korupsi. Pembahasan ini dilakukan untuk mengetahui pengaturan mengenai pidana tambahan berupa pembayaran uang pengganti dan bagaiamana tata cara pembayaran uang pengganti tersebut yang diatur dalam Undang-Undang Nomor 31 Tahun 1999 Tentang Pemberantasan Tindak Pidana Korupsi sebagaimana telah diubah dengan Undang-Undang Nomor 20 Tahun 2001 Tentang Perubahan Atas Undang-Undang Nomor 31 Tahun 1999 Tentang Pemberantasan Tindak Pidana Korupsi. 
Korupsi adalah perbuatan yang membahayakan terhadap kelangsungan hidup bernegara. Dampak negatif yang ditimbulkan oleh tindak pidana korupsi lebih dahsyat dari bencana alam atau perang sekalipun. Di Indonesia, perbuatan ini telah bertumbuh bahkan berkembang seperti jamur saat musim hujan, dan akan sangat sulit untuk diberantas jika pemerintah dan pihak-pihak terkait tidak melakukan tindakan nyata. Pemberantasan yang dilakukan terhadap tindak pidana korupsi belum dilaksanakan dengan baik sebagaimana mestinya sampai saat ini. Oleh sebab itu, diperlukannya peningkatan yang baik tentunya secara profesional, intensif dan berkesinambungan dalam melakukan pemberantasan tindak pidana korupsi, dimana perbuatan tersebut telah membuat negara mengalami kerugian dalam hal keuangan, perekonomian negara, dan menghambat pembangunan nasional. ${ }^{1}$

Tindak pidana korupsi di Indonesia telah memiliki suatu ketentuan hukum yang mengatur mengenai perbuatan yang dianggap merusak bangsa dan negara baik dalam segi ekonomi dan segi moral. Akibat yang ditimbulkan dari tindak pidana korupsi selain merugikan perorangan, namun juga merugikan perekonomian negara yang berdampak pada terhambatnya pembangunan negara ke arah yang lebih baik, peningkatan kesejahteraan dan pengentasan kemiskinan rakyat.

Korupsi menghambat pengembangan demokrasi, menghambat pelaksanaan tugas lembaga-lembaga publik dan penggunaan sumber daya secara optimal. Korupsi memupuk perilaku merahasiakan segala sesuatu dan penindasan. Pada akhirnya korupsi menutup kemungkinan bagi warga masyarakat yang paling lemah untuk turut menikmati pembangunan dan mutu kehidupan yang lebih tinggi. $^{2}$

Dalam tindak pidana korupsi sebagai kejahatan luar biasa (extra ordinary crime) mewajibkan negara melalui penegak hukum untuk bertanggung jawab mengembalikan kerugian negara yang ditimbulkan akibat tindak pidana korupsi. Pengembalian aset merupakan salah satu tujuan pemidanaan dalam hukum tindak pidana korupsi dan tindak pidana pencucian uang.

Matthew H Fleming menjelaskan bahwa pengembalian aset adalah proses pelaku-pelaku kejahatan dicabut, dirampas, dihilangkan haknya dari hasil tindak pidana. Pendapat Fleming tersebut lebih menekankan pada tiga faktor, yaitu: pertama, pengembalian aset sebagai proses pencabutan, perampasan, penghilangan; kedua, yang dicabut, dirampas dan dihilangkan adalah hasil/keuntungan yang diperoleh dari tindak pidana korupsi; dan ketiga, salah satu tujuan pencabutan, perampasan, penghilangan adalah agar pelaku tindak pidana tidak dapat menggunakan hasil/keuntungan-keuntungan dari tindak pidana sebagai alat/sarana untuk melakukan tindak pidana lainnya. ${ }^{3}$

Secara harfiah korupsi berarti kebusukan, keburukan, kejahatan, ketidak jujuran, dapat di suap, penyimpangan dari kesucian, kata-kata yang bernuansa menghina atau

1 Hafrida, “Analisis Penerapan Pasal 2 Undang-Undang Nomor 31 Tahun 1999 Jo UndangUndang Nomor 20Tahun 2001 Tentang Tindak Pidana Korupsi Pada Perkara No. 01/Pid.B/Tpk/2012/Pn. Jbi.", Jurnal Ilmu Hukum, 6, 2, (2013), hlm. 32

2 Jeremy Pope, Strategi Memberantas Korupsi Elemen Sistem Integrtas Nasional, (Jakarta: Yayasan Obor Indonesia, 2007), hlm. 6.

3 Ade Muhammad, Problematika Asset Recovery Dalam Pengembalian Kerugian Negara Akibat Tindak Pidana Korupsi, http://jurnal.komisiyudisial.go.id/index.php/jy/article/view/262 diakses 292019/ 3 /. 
memfitnah, penyuapan, dalam bahasa Indonesia kata korupsi adalah perbuatan buruk, seperti penggelapan uang penerimaan, uang sogok dan sebagainya. Kemudian arti kata korupsi telah diterima dalam pembendaharaan bahasa Indonesia dalam kamus besar Indonesia yaitu kecurangan dalam melakukan kewajiban sebagai pejabat. ${ }^{4}$ Menurut Undang-Undang Nomor 31 Tahun 1999 tentang Pemberantasan Tindak Pidana Korupsi sebagaimana telah diubah dengan Undang-Undang Nomor 20 Tahun 2001 tentang Perubahan Atas Undang-Undang Nomor 31 Tahun 1999 tentang Pemberantasan Tindak Pidana Korupsi bentuk sanksi pidana yang dapat dikenakan terhadap pelaku tindak pidana korupsi adalah pidana penjara dan pidana denda, tergantung bobot dan kualifikasi tindak pidana korupsi yang dilakukan.

Selain dari sanksi pidana berupa pidana penjara dan pidana denda pelaku tindak pidana korupsi juga dapat dijatuhi pidana tambahan berupa penutupan perusahaan, perampasan barang, pembayaran uang pengganti, pencabutan hak dan penghapusan keuntungan, sebagaimana dijelaskan dalam Pasal 17 Undang-Undang Nomor 31 Tahun 1999 tentang Pemberantasan Tindak Pidana Korupsi sebagaimana telah diubah dengan Undang-Undang Nomor 20 Tahun 2001 tentang Perubahan Atas UndangUndang Nomor 31 Tahun 1999 tentang Pemberantasan Tindak Pidana Korupsi yang menentukan "Selain dapat dijatuhi pidana sebagaimana dimaksud dalam Pasal 2, Pasal 3, Pasal 5 sampai dengan Pasal 14, terdakwa dapat dijatuhi pidana tambahan sebagaimana dimaksud dalam Pasal 18."

Sedangkan ketentuan Pasal 18 menentukan:

Ayat (1) Selain pidana tambahan sebagaimana dimaksud dalam Kitab UndangUndang Hukum Pidana, sebagai pidana tambahan adalah:

a. perampasan barang bergerak yang berwujud atau tidak berwujud atau tidak bergerak yang digunakan atau yang usahaan milik terpidana dimana tindak pidana korupsi dilakukan, begitu pula barang yang menggantikan barangbarang tersebut;

b. pembayaran uang pengganti yang jumlahnya sebanyak-banyaknya sama dengan harta benda yang diperoleh dari tindak pidana korupsi;

c. penutupan seluruh atau sebagian perusahaan untuk waktu paling lama 1 (satu) tahun;

d. pencabutan seluruh atau sebagian hak-hak tertentu atau penghapusan seluruh atau sebagian keuntungan tertentu, yang telah atau dapat diberikan oleh Pemerintah kepada terpidana.

Ayat (2) Jika terpidana tidak membayar uang pengganti sebagaimana dimaksud dalam Ayat (1) huruf b paling lama dalam waktu 1 (satu) bulan sesudah putusan pengadilan yang telah memperoleh kekuatan hukum tetap, maka harta bendanya dapat disita oleh jaksa dan dilelang untuk menutupi uang pengganti tersebut.

Ayat (3) Dalam hal terpidana tidak mempunyai harta benda yang mencukupi untuk membayar uang pengganti sebagaimana dimaksud dalam Ayat (1) huruf b, maka dipidana dengan pidana penjara yang lamanya tidak melebihi ancaman maksimum dari pidana pokoknya sesuai dengan ketentuan dalam UndangUndang ini dan lamanya pidana tersebut sudah ditentukan dalam putusan pengadilan.

4 Hamzah Ahmad dan Anando Santoso, Kamus Pintar Bahasa Indonesia, Fajar Mulia, Surabaya, 1996, Hal. 211. 
Salah satu pidana tambahan Undang-Undang Nomor 31 Tahun 1999 Tentang Pemberantasan Tindak Pidana Korupsi sebagaimana telah diubah dengan UndangUndang Nomor 20 Tahun 2001 tentang Perubahan Atas Undang-Undang Nomor 31 Tahun 1999 tentang Pemberantasan Tindak Pidana Korupsi adalah membayar uang pengganti. Denifisi pembayaran uang pengganti itu sendiri adalah suatu bentuk pengembalian kerugian negara yang diakibatkan oleh perbuatan korupsi yang dilakukan terdakwa. ${ }^{5}$ Namun sampai saat ini pembebanan uang pengganti bagi terdakwa sebagai pidana tambahan selain pidana penjara belum sesuai dengan apa yang diharapkan dan diidam-idamkan oleh pembuat Undang-Undang Nomor 31 Tahun 1999 Tentang Pemberantasan Tindak Pidana Korupsi sebagaimana telah diubah dengan Undang-Undang Nomor 20 Tahun 2001 Tentang Perubahan Atas UndangUndang Nomor 31 Tahun 1999 Tentang Pemberantasan Tindak Korupsi.

Kaidah ini menunjukkan bahwa dasar hukum upaya pengembalian kerugian negara melalui pidana pembayaran uang pengganti telah ada. Kenyataan dalam praktik peradilan menunjukkan bahwa hakim telah menjatuhkan putusan pidana uang pengganti sesuai dengan kerugian keuangan negara yang ditimbulkan akibat tindak pidana korupsi, namun saat akan dieksekusi jaksa, terpidana mengakui dirinya tidak memiliki harta yang cukup untuk membayar pidana uang pengganti yang lamanya tidak melebihi pidana pokok yang dijatuhkan seperti ditentukan dalam Pasal 18 Ayat (3) Undang-Undang Nomor 31 Tahun 1999 Tentang Pemberantasan Tindak Pidana Korupsi sebagaimana telah diubah dengan Undang-Undang Nomor 20 Tahun 2001 Tentang Perubahan Atas Undang-Undang Nomor 31 Tahun 1999 Tentang Pemberantasan Tindak Pidana Korupsi.

Dalam Pasal 18 Ayat (1) huruf b Undang-Undang Nomor 31 Tahun 1999 Tentang Pemberantasan Tindak Pidana Korupsi sebagaimana telah diubah dengan UndangUndang Nomor 20 Tahun 2001 tentang Perubahan Atas Undang-Undang Nomor 31 Tahun 1999 tentang Pemberantasan Tindak Pidana Korupsi tersebut telah memberikan penekanan khusus mengenai berapa besarnya uang pengganti yang dapat dibebankan kepada terdakwa yakni sebanyak-banyaknya sama dengan harta benda yang diperoleh dari tindak pidana korupsi. Dengan adanya aturan ini, negara berarti menginginkan adanya pemulihan terhadap kerugian yang ditimbulkan oleh tindak pidana korupsi.

Tetapi dalam Pasal 18 Ayat (3) menjelaskan:

Dalam hal terpidana tidak mempunyai harta benda yang mencukupi untuk membayar uang pengganti sebagaimana dimaksud dalam ayat (1) huruf $b$, maka dipidana dengan pidana penjara yang lamanya tidak melebihi ancaman maksimum dari pidana pokoknya sesuai dengan ketentuan dalam UndangUndang ini dan lamanya pidana tersebut sudah ditentukan dalam putusan pengadilan.

Aturan ini menimbulkan problem yuridis karena satu sisi memiliki semangat pemulihan aset melalui kebijakan pembayaran uang pengganti, tetapi di pihak lain

5 Adly, "Pidana Denda dan Uang Pengganti Terhadap Terpidana Dalam Tindak Pidana Korupsi (Studi Komparatif Hukum Indonesia dan Malaysia)" (disertasi, Universitas Jambi, Jambi, 2017), hlm. 6. 
memberikan peluang bagi terpidana untuk memilih membayar uang pengganti atau menjalani pidana subsider. ${ }^{6}$ Problematika yang muncul dalam upaya pemulihan aset dalam perkara tindak pidana korupsi adalah mengenai putusan hakim yang berupaya menjatuhkan pidana tambahan berupa uang pengganti, akan tetapi selalu dibenturkan dengan keadaan ekonomi terpidana yang tidak mampu untuk membayar lunas uang pengganti. Akibatnya pidana uang pengganti sebagai upaya pengembalian kerugian negara disubsiderkan dengan pidana penjara, sehingga putusan hakim tidak dapat mewujudkan harapan mencapai keadilan ekonomi. Putusan pengadilan seperti ini tidak mungkin mampu memulihkan kerugian negara akibat tindak pidana korupsi dan tidak akan menimbulkan efek jera. Dalam prakteknya pidana penjara pengganti sebagaimana dimaksud dalam Pasal 18 Ayat (3) yang disebutkan dalam putusan hakim tidak seimbang karena nilai uang pengganti yang jumlahnya ratusan juta sampai miliaran rupiah disubsiderkan dengan pidana penjara yang relatif singkat.

Berikut adalah Putusan Perkara Tindak Pidana Korupsi di Pengadilan Negeri Jambi Tahun 2018 yang menjatuhkan pidana tambahan uang pengganti disertai pidana penjara pengganti (subsider):

\begin{tabular}{|c|c|c|c|c|}
\hline No & No. Perkara & $\begin{array}{c}\text { Nama } \\
\text { Tersangka }\end{array}$ & $\begin{array}{l}\text { Pasal Yang } \\
\text { Dilanggar }\end{array}$ & Putusan Akhir \\
\hline 1 & $\begin{array}{l}\text { 1/Pid.Sus- } \\
\text { TPK/2018/PN } \\
\text { Jmb }\end{array}$ & $\begin{array}{l}\text { FARIDA } \\
\text { HERYANI Binti } \\
\text { ABDUL LANI }\end{array}$ & $\begin{array}{l}\text { Pasal } 3 \text { Jo } \\
\text { Pasal } 18 \text { UU } \\
\text { No. } 31 \\
\text { Tahun } 1999 \\
\text { sebagaimana } \\
\text { telah diubah } \\
\text { dengan UU } \\
\text { No. } 20 \\
\text { Tahun } 2001 \\
\text { Jo Pasal } 65 \\
\text { Ayat (1) } \\
\text { KUHP }\end{array}$ & $\begin{array}{l}\text { Pidana Penjara (1 } \\
\text { Tahun) Pidana } \\
\text { Denda (Rp. } \\
50.000 .000 \text {, subsider } \\
6 \text { bulan) Uang } \\
\text { Pengganti } \\
\text { (Rp.50.000.000, } \\
\text { subsider 1 Bulan) }\end{array}$ \\
\hline 2 & $\begin{array}{l}\text { 7/Pid.Sus- } \\
\text { TPK/2018/PN } \\
\text { Jmb }\end{array}$ & $\begin{array}{l}\text { ZAM ZAMI, SE } \\
\text { Bin } \\
\text { MUHAMMAD } \\
\text { SALEH TUAH }\end{array}$ & $\begin{array}{l}\text { Pasal } 3 \text { Jo } \\
\text { Pasal } 18 \\
\text { Ayat (1) } \\
\text { huruf b UU } \\
\text { No. } 31 \\
\text { Tahun } 1999 \\
\text { sebagaimana } \\
\text { telah diubah } \\
\text { dengan UU } \\
\text { No. } 20 \\
\text { Tahun } 2001 \\
\text { Jo Pasal } 64 \\
\text { Ayat (1) } \\
\text { KUHP }\end{array}$ & $\begin{array}{l}\text { Pidana Penjara (1 } \\
\text { Tahun) Pidana } \\
\text { Denda (Rp. } \\
50.000 .000 \text {, subsider } \\
1 \text { bulan) Uang } \\
\text { Pengganti } \\
\text { (Rp.10.518.379, } \\
\text { subsider 1 Bulan) }\end{array}$ \\
\hline 3 & $\begin{array}{l}\text { 13/Pid.Sus- } \\
\text { TPK/2018/PN }\end{array}$ & $\begin{array}{l}\text { MUHAMMAD } \\
\text { JAMAAH Bin }\end{array}$ & $\begin{array}{l}\text { Pasal } 3 \text { Jo } \\
\text { Pasal } 18 \text { UU }\end{array}$ & $\begin{array}{l}\text { Pidana Penjara (1 } \\
\text { Tahun } 4 \text { Bulan) }\end{array}$ \\
\hline
\end{tabular}

6 Fontian Munzil, dkk, "Kesebandingan Pidana Uang Pengganti dan Pengganti Pidana Uang Pegganti Dalam Rangka Melindungi Hak Ekonomi Negara dan Kepastian Hukum”, Jurnal Hukum Ius Quia Iustum, 22, 1, (2015), hlm. 42. 


\begin{tabular}{|c|c|c|c|c|}
\hline & Jmb & PAJI & $\begin{array}{l}\text { No. } 31 \\
\text { Tahun } 1999 \\
\text { sebagaimana } \\
\text { telah diubah } \\
\text { dengan UU } \\
\text { No. } 20 \\
\text { Tahun } 2001\end{array}$ & $\begin{array}{l}\text { Pidana Denda (Rp. } \\
50.000 .000, \text { subsider } \\
1 \text { Bulan) Uang } \\
\text { Pengganti } \\
\text { (Rp.487.500.000, } \\
\text { subsider } 6 \text { Bulan) }\end{array}$ \\
\hline 4 & $\begin{array}{l}\text { 16/Pid.Sus- } \\
\text { TPK/2018/PN } \\
\text { Jmb }\end{array}$ & $\begin{array}{l}\text { AWALUDDIN } \\
\text { Bin TULUS }\end{array}$ & $\begin{array}{l}\text { Pasal } 2 \text { Jo } \\
\text { Pasal } 18 \text { UU } \\
\text { No. } 31 \\
\text { Tahun } 1999 \\
\text { sebagaimana } \\
\text { telah diubah } \\
\text { dengan UU } \\
\text { No. } 20 \\
\text { Tahun } 2001 \\
\text { Jo Pasal } 55 \\
\text { Ayat (1) } \\
\text { KUHP }\end{array}$ & $\begin{array}{l}\text { Pidana Penjara (2 } \\
\text { Tahun) Pidana } \\
\text { Denda (Rp. } \\
\text { 50.000.000, subsider } \\
1 \text { Bulan) Uang } \\
\text { Pengganti } \\
\text { (Rp.342.231.499,10, } \\
\text { subsider } 1 \text { Bulan) }\end{array}$ \\
\hline 5 & $\begin{array}{l}\text { 21/Pid.Sus- } \\
\text { TPK/2018/PN } \\
\text { Jmb }\end{array}$ & $\begin{array}{l}\text { SYAMLAWI Bin } \\
\text { MARZUKI }\end{array}$ & $\begin{array}{l}\text { Pasal } 2 \text { Ayat } \\
\text { (1) Jo Pasal } \\
18 \text { UU No. } \\
31 \text { Tahun } \\
1999 \\
\text { sebagai } \\
\text { mana telah } \\
\text { diubah } \\
\text { dengan UU } \\
\text { No. } 20 \\
\text { Tahun } 2001 \\
\text { Jo. Pasal } 55 \\
\text { Ayat (1) } \\
\text { KUHP }\end{array}$ & $\begin{array}{l}\text { Pidana Penjara (4 } \\
\text { Tahun) Pidana } \\
\text { Denda (Rp. } \\
\text { 200.000.000, } \\
\text { subsider } 1 \text { Bulan) } \\
\text { Uang Pengganti } \\
\text { (Rp.106.399.627,5, } \\
\text { subsider } 1 \text { Tahun) }\end{array}$ \\
\hline 6 & $\begin{array}{l}\text { 22/Pid.Sus- } \\
\text { TPK/2018/PN } \\
\text { Jmb }\end{array}$ & $\begin{array}{l}\text { MUHAMMAD } \\
\text { YUSUF, Sp Bin } \\
\text { H. A. RAHMAN }\end{array}$ & $\begin{array}{l}\text { Pasal } 2 \text { Ayat } \\
\text { (1) Jo Pasal } \\
18 \text { UU No. } \\
31 \text { Tahun } \\
1999 \\
\text { sebagai } \\
\text { mana telah } \\
\text { diubah } \\
\text { dengan UU } \\
\text { No. } 20 \\
\text { Tahun } 2001 \\
\text { Jo. Pasal } 55 \\
\text { Ayat (1) } \\
\text { KUHP }\end{array}$ & $\begin{array}{l}\text { Pidana Penjara (4 } \\
\text { Tahun) Pidana } \\
\text { Denda (Rp. } \\
\text { 200.000.000, } \\
\text { subsider } 1 \text { Bulan) } \\
\text { Uang Pengganti } \\
\text { (Rp.106.399.627,5, } \\
\text { subsider } 1 \text { Tahun) }\end{array}$ \\
\hline 7 & $\begin{array}{l}\text { 26/Pid.Sus- } \\
\text { TPK/2018/PN } \\
\text { Jmb }\end{array}$ & $\begin{array}{l}\text { HAFIFULLAH } \\
\text { SINWANI, S. T } \\
\text { Bin H. } \\
\text { MUHAMMAD } \\
\text { ALI }\end{array}$ & $\begin{array}{l}\text { Pasal } 10 \\
\text { Huruf a Jo } \\
\text { Pasal } 18 \\
\text { Ayat (1) } \\
\text { huruf b, Ayat } \\
\text { (2), Ayat (3) }\end{array}$ & $\begin{array}{l}\text { Pidana Penjara (2 } \\
\text { Tahun } 6 \text { Bulan) } \\
\text { Pidana Denda (Rp. } \\
\text { 100.000.000, } \\
\text { subsider } 6 \text { Bulan) } \\
\text { Uang Pengganti }\end{array}$ \\
\hline
\end{tabular}




\begin{tabular}{|c|c|c|c|c|}
\hline & & & $\begin{array}{l}\text { UU No. } 31 \\
\text { Tahun } 1999 \\
\text { sebagai } \\
\text { mana telah } \\
\text { diubah } \\
\text { dengan UU } \\
\text { No. } 20 \\
\text { Tahun } 2001\end{array}$ & $\begin{array}{l}\text { (Rp.84.294.072, } \\
\text { subsider } 6 \text { Bulan }\end{array}$ \\
\hline 8 & $\begin{array}{l}\text { 27/Pid.Sus- } \\
\text { TPK/2018/PN } \\
\text { Jmb }\end{array}$ & $\begin{array}{l}\text { Ir. SARJONO Bin } \\
\text { ZAMRI }\end{array}$ & $\begin{array}{l}\text { Pasal } 3 \text { Jo } \\
\text { Pasal } 18 \text { UU } \\
\text { No. } 31 \\
\text { Tahun } 1999 \\
\text { sebagaimana } \\
\text { telah diubah } \\
\text { dengan UU } \\
\text { No. } 20 \\
\text { Tahun } 2001 \\
\text { Jo Pasal } 55 \\
\text { Ayat (1) Ke- } \\
1 \text { KUHP }\end{array}$ & $\begin{array}{l}\text { Pidana Penjara (1 } \\
\text { Tahun } 8 \text { Bulan) } \\
\text { Pidana Denda (Rp. } \\
\text { 50.000.000, subsider } \\
3 \text { Bulan) Uang } \\
\text { Pengganti } \\
\text { (Rp.80.000.000, } \\
\text { subsider } 1 \text { Tahun }\end{array}$ \\
\hline 9 & $\begin{array}{l}\text { 29/Pid.Sus- } \\
\text { TPK/2018/PN } \\
\text { Jmb }\end{array}$ & $\begin{array}{l}\text { Ir. JONAITA } \\
\text { NASIR Als } \\
\text { JONET Bin } \\
\text { AHMAD NASIR }\end{array}$ & $\begin{array}{l}\text { Pasal } 3 \text { Jo } \\
\text { Pasal } 18 \text { UU } \\
\text { No. } 31 \\
\text { Tahun } 1999 \\
\text { sebagaimana } \\
\text { telah diubah } \\
\text { dengan UU } \\
\text { No. } 20 \\
\text { Tahun } 2001 \\
\text { Jo Pasal } 55 \\
\text { Ayat (1) Ke- } \\
1 \text { KUHP }\end{array}$ & $\begin{array}{l}\text { Pidana Penjara (2 } \\
\text { Tahun) Pidana } \\
\text { Denda (Rp. } \\
\text { 50.000.000, subsider } \\
3 \text { Bulan) Uang } \\
\text { Pengganti } \\
\text { (Rp.335.388.415,41, } \\
\text { subsider } 1 \text { Tahun) }\end{array}$ \\
\hline 10 & $\begin{array}{l}\text { 30/Pid.Sus- } \\
\text { TPK/2018/PN } \\
\text { Jmb }\end{array}$ & $\begin{array}{l}\text { FAISAL UTAMA, } \\
\text { S.Kom Bin } \\
\text { DAMAN HURI }\end{array}$ & $\begin{array}{l}\text { Pasal } 3 \text { Jo } \\
\text { Pasal } 18 \text { UU } \\
\text { No. } 31 \\
\text { Tahun } 1999 \\
\text { sebagaimana } \\
\text { telah diubah } \\
\text { dengan UU } \\
\text { No. } 20 \\
\text { Tahun } 2001 \\
\text { Jo Pasal } 55 \\
\text { Ayat (1) Ke- } \\
1 \text { KUHP }\end{array}$ & $\begin{array}{l}\text { Pidana Penjara ( } 2 \\
\text { Tahun) Pidana } \\
\text { Denda (Rp. } \\
\text { 50.000.000, subsider } \\
3 \text { Bulan) Uang } \\
\text { Pengganti } \\
\text { (Rp.335.388.415,41, } \\
\text { subsider } 1 \text { Tahun) }\end{array}$ \\
\hline 11 & $\begin{array}{l}\text { 34/Pid.Sus- } \\
\text { TPK/2018/PN } \\
\text { Jmb }\end{array}$ & $\begin{array}{l}\text { ARY } \\
\text { FEBRIYANSYAH, } \\
\text { SE Bin SOFYAN } \\
\text { ARYANA } \\
\text { HIDAYAT }\end{array}$ & $\begin{array}{l}\text { Pasal } 2 \text { Ayat } \\
\text { (1) Jo Pasal } \\
18 \text { UU No. } \\
31 \text { Tahun } \\
1999 \\
\text { sebagai } \\
\text { mana telah } \\
\text { diubah } \\
\text { dengan UU }\end{array}$ & $\begin{array}{l}\text { Pidana Penjara (5 } \\
\text { Tahun } 6 \text { Bulan) } \\
\text { Pidana Denda (Rp. } \\
\text { 200.000.000, } \\
\text { subsider } 3 \text { Bulan) } \\
\text { Uang Pengganti } \\
\text { (Rp.1.266.830.000, } \\
\text { subsider } 1 \text { Tahun) }\end{array}$ \\
\hline
\end{tabular}




\begin{tabular}{|c|c|c|c|c|}
\hline & & & $\begin{array}{l}\text { No. } 20 \\
\text { Tahun } 2001 \\
\text { Jo. Pasal } 55 \\
\text { Ayat (1) } \\
\text { KUHP Jo } \\
\text { Pasal 64 } \\
\text { Ayat (1) } \\
\text { KUHP }\end{array}$ & \\
\hline 12 & $\begin{array}{l}\text { 35/Pid.Sus- } \\
\text { TPK/2018/PN } \\
\text { Jmb }\end{array}$ & $\begin{array}{l}\text { ILHAM TAUFIQ } \\
\text { Bin H. AHMADI } \\
\text { TAMYIZ }\end{array}$ & $\begin{array}{l}\text { Pasal } 2 \text { Ayat } \\
\text { (1) Jo Pasal } \\
18 \text { UU No. } \\
31 \text { Tahun } \\
1999 \\
\text { sebagai } \\
\text { mana telah } \\
\text { diubah } \\
\text { dengan UU } \\
\text { No. 20 } \\
\text { Tahun } 2001 \\
\text { Jo. Pasal } 55 \\
\text { Ayat (1) } \\
\text { KUHP Jo } \\
\text { Pasal 64 } \\
\text { Ayat (1) } \\
\text { KUHP }\end{array}$ & $\begin{array}{l}\text { Pidana Penjara (6 } \\
\text { Tahun) Pidana } \\
\text { Denda (Rp. } \\
\text { 200.000.000, } \\
\text { subsider } 3 \text { Bulan) } \\
\text { Uang Pengganti } \\
\text { (Rp.1.236.830.000, } \\
\text { subsider } 6 \text { Bulan) }\end{array}$ \\
\hline 13 & $\begin{array}{l}\text { 38/Pid.Sus- } \\
\text { TPK/2018/PN } \\
\text { Jmb }\end{array}$ & $\begin{array}{l}\text { TARMIZI Bin } \\
\text { ISMAIL }\end{array}$ & $\begin{array}{l}\text { Pasal } 3 \text { Jo } \\
\text { Pasal } 18 \\
\text { Ayat (1) } \\
\text { huruf b UU } \\
\text { No. } 31 \\
\text { Tahun } 1999 \\
\text { sebagaimana } \\
\text { telah diubah } \\
\text { dengan UU } \\
\text { No. } 20 \\
\text { Tahun } 2001 \\
\text { Jo Pasal 55 } \\
\text { Ayat (1) Ke- } \\
1 \text { KUHP }\end{array}$ & $\begin{array}{l}\text { Pidana Penjara (2 } \\
\text { Tahun) Pidana } \\
\text { Denda (Rp. } \\
\text { 50.000.000, subsider } \\
2 \text { Bulan) Uang } \\
\text { Pengganti } \\
\text { (Rp.160.769.500, } \\
\text { subsider } 1 \text { Tahun) }\end{array}$ \\
\hline 14 & $\begin{array}{l}\text { 39/Pid.Sus- } \\
\text { TPK/2018/PN } \\
\text { Jmb }\end{array}$ & $\begin{array}{l}\text { HERIYAH, S.Pd } \\
\text { Binti H. ISMAIL } \\
\text { HADI }\end{array}$ & $\begin{array}{l}\text { Pasal } 8 \text { Ayat } \\
\text { (1) Jo Pasal } \\
18 \text { UU No. } \\
31 \text { Tahun } \\
1999 \\
\text { sebagai } \\
\text { mana telah } \\
\text { diubah } \\
\text { dengan UU } \\
\text { No. 20 } \\
\text { Tahun } 2001 \\
\text { Jo Pasal } 64 \\
\text { Ayat (1) } \\
\text { KUHP }\end{array}$ & $\begin{array}{l}\text { Pidana Penjara (3 } \\
\text { Tahun) Pidana } \\
\text { Denda (Rp. } \\
\text { 150.000.000, } \\
\text { subsider } 2 \text { Bulan) } \\
\text { Uang Pengganti } \\
\text { (Rp.1.068.481.100, } \\
\text { subsider } 4 \text { Bulan) }\end{array}$ \\
\hline
\end{tabular}




\begin{tabular}{|c|c|c|c|c|}
\hline 15 & $\begin{array}{l}\text { 43/Pid.Sus- } \\
\text { TPK/2018/PN } \\
\text { Jmb }\end{array}$ & $\begin{array}{l}\text { WENDI LEO, ST } \\
\text { Bin WANJANI } \\
\text { HOLIDI }\end{array}$ & $\begin{array}{l}\text { Pasal } 3 \text { Jo } \\
\text { Pasal } 18 \text { UU } \\
\text { No. } 31 \\
\text { Tahun } 1999 \\
\text { sebagaimana } \\
\text { telah diubah } \\
\text { dengan UU } \\
\text { No. } 20 \\
\text { Tahun } 2001 \\
\text { Jo Pasal } 55 \\
\text { Ayat (1) Ke- } \\
1 \text { KUHP }\end{array}$ & $\begin{array}{l}\text { Pidana Penjara (2 } \\
\text { Tahun } 6 \text { Bulan) } \\
\text { Pidana Denda (Rp. } \\
\text { 50.000.000, subsider } \\
3 \text { Bulan) Uang } \\
\text { Pengganti } \\
\text { (Rp.6.060.592.228,7 } \\
\text { 9, subsider } 1 \text { Tahun) }\end{array}$ \\
\hline 16 & $\begin{array}{l}\text { 44/Pid.Sus- } \\
\text { TPK/2018/PN } \\
\text { Jmb }\end{array}$ & $\begin{array}{l}\text { Drs. ELFIAN Bin } \\
\text { ZAINAL ABIDIN }\end{array}$ & $\begin{array}{l}\text { Pasal 3 Jo } \\
\text { Pasal 18 } \\
\text { Ayat (1)Jo } \\
\text { Pasal 18 } \\
\text { Ayat (1), } \\
\text { Ayat (2) dan } \\
\text { Ayat (3) UU } \\
\text { No. 31 } \\
\text { Tahun } 1999 \\
\text { sebagai } \\
\text { mana telah } \\
\text { diubah } \\
\text { dengan UU } \\
\text { No. 20 } \\
\text { Tahun 2001 } \\
\text { Jo Pasal } 64 \\
\text { Ayat (1) } \\
\text { KUHP }\end{array}$ & $\begin{array}{l}\text { Pidana Penjara (2 } \\
\text { Tahun } 6 \text { Bulan) } \\
\text { Pidaa Denda (Rp. } \\
\text { 100.000.000, } \\
\text { subsider } 3 \text { Bulan) } \\
\text { Uang Pengganti } \\
\text { (Rp.220.795.965, } \\
\text { subsider 6 Bulan) }\end{array}$ \\
\hline
\end{tabular}

Dari Putusan Perkara Tindak Pidana Korupsi di Pengadilan Negeri Jambi Tahun 2018 tersebut dapat dilihat bahwa dalam praktiknya penjatuhan pidana tambahan uang pengganti yang disertai dengan pidana penjara pengganti menunjukkan ketidakseimbangan antara besarnya uang pengganti dengan pidana penjara pengganti yang dijatuhkan.

Negara menyimpan harapan besar bahwa Undang-Undang Pemberantasan Tindak Pidana Korupsi ini dapat memulihkan kerugian negara yang diakibatkan oleh tindak pidana korupsi melalui aturan pidana tambahan tetapi dalam kenyataan aturan normatif justru memberikan kelonggaran terhadap pelaku untuk lolos dari kewajiban membayar uang pengganti dan tetap bisa menikmati hasil tindak pidana korupsi.

\section{B. METODE PENELITIAN}

Tipe penelitian ini adalah tipe penelitian normatif, yaitu penelitian yang dilakukan atau dituju hanya pada peraturan-peraturan tertulis atau bahan-bahan hukum terdiri dari bahan primer meliputi peraturan perundangan, bahan hukum sekunder terdiri dari buku, jurnal, dan literatur lainnya.

\section{PEMBAHASAN}




\section{Pengaturan Pengembalian Kerugian Negara Melalui Pembayaran Uang} Pengganti Berdasarkan Putusan Hakim Pengadilan Tindak Pidana Korupsi

\section{(Studi Kasus di Pengadilan Negeri Jambi)}

Pidana pembayaran uang pengganti pertama kali diatur dalam Peraturan Pemerintah Pengganti Undang-UndangNomor 24 Tahun 1960 tentang Pengusutan, Penuntutan dan Pemeriksaan Tindak Pidana Korupsi (Tipikor). Instrumen ini kemudian diteruskan dalam Undang-Undang Nomor 3 Tahun 1971 dan UndangUndang Nomor 31 Tahun 1999 tentang Pemberantasan Tindak Pidana Korupsi jo. Undang-Undang Nomor 20 Tahun 2001 Tentang Perubahan Atas Undang-Undang Nomor 31 Tahun 1999 Tentang Pemberantasan Tindak Pidana Korupsi yang menyebutkan bahwa pidana pembayaran uang pengganti merupakan salah satu pidana tambahan dalam perkara korupsi selain pidana tambahan sebagaimana dimaksud dalam Kitab Undang-Undang Hukum Pidana. Disahkannya Undang-Undang Nomor 20 Tahun 2001 Tentang Perubahan Atas Undang-Undang Nomor 31 Tahun 1999 Tentang Pemberantasan Tindak Pidana Korupsi, maka aturan mengenai pembayaran uang pengganti semakin jelas sebagaimana dijelaskan dalam Pasal 17 dan Pasal 18 bahwa perkara korupsi tersebut juga dapat dijatuhi hukuman pidana tambahan, yaitu:

a. Perampasan barang bergerak yang berwujud dan tidak berwujud atau barang tidak bergerak yang digunakan untuk atau yang diperoleh dari tindak pidana korupsi, termasuk perusahaan milik terpidana dimana tindak pidana korupsi dilakukan, begitu pula barang yang menggantikan barang-barang tersebut.

b. Pembayaran uang pengganti yang jumlahnya sebanyak-banyaknya sama dengan harta benda yang diperoleh dari tindak pidana korupsi.

c. Penutupan seluruh atau sebagian perusahaan untuk waktu paling lama 1 (satu) tahun.

d. Pencabutan seluruh atau sebagian hak-hak tertentu atau penghapusan seluruh atau sebagian keuntungan tertentu, yang telah atau dapat diberikan oleh Pemerintah kepada terpidana.

Uang pengganti bukan baru dirumuskan pada tahun 1999 melalui UndangUndang Nomor 31 Tahun 1999, namun jenis pidana tambahan ini pertama kali diperkenalkan pada tahun 1960 melalui Perppu Nomor 24 Tahun 1960 Tentang Pengusutan, Penuntutan dan Pemeriksaan Tindak Pidana Korupsi.

Pasal 16:

(1) Barangsiapa melakukan tindak pidana korupsi yang dimaksud dalam Pasal 1 sub a dan $b$ dihukum dengan hukuman penjara selama-lamanya dua belas tahun dan/atau denda setinggi-tingginya satu juta rupiah.

(2) Segala harta benda yang diperoleh dari korupsi itu dirampas.

(3) Si Terhukum dapat juga diwajibkan membayar uang pengganti yang jumlahnya sama dengan harta benda yang diperoleh dari korupsi.

Selanjutnya di dalam Undang-Undang Nomor 3 Tahun 1971 Tentang Pemberantasan Tindak Pidana Korupsi juga telah mengatur tentang uang pengganti, yaitu dirumuskan kedalam salah satu pasal yakni pasal 34 huruf c.

Pasal 34:

Selain ketentuan-ketentuan Pidana sebagaimana dimaksud dalam K.U.H.P. maka sebagai hukuman tambahan adalah: 
a. Perampasan barang-barang tetap maupun tak tetap yang berujud dan yang tak berujud, dengan mana atau mengenai mana tindak pidana itu dilakukan atau yang seluruhnya atau sebagian diperolehnya dengan tindak pidana korupsi itu, begitu pula harga lawan barang-barang yang menggantikan barang-barang itu, baik apakah barang-barang atau harga lawan itu kepunyaan siterhukum atau bukan;

b. Perampasan barang-barang tetap atau tak tetap yang berujud dan tak berujud yang termaksud perusahaan siterhukum, dimana tindak pidana itu dilakukan begitu pula harga lawan barang-barang yang menggantikan barang-barang itu, baik apakah barang-barang atau harga lawan itu kepunyaan siterhukum atau bukan, akan tetapi tindak pidananya bersangkutan dengan barangbarang yang diampas menurut ketentuan tersebut sub a pasal ini.

c. Pembayaran uang pengganti yang jumlahnya sebanyak-banyaknya sama dengan harta benda yang diperoleh dari korupsi.

Selanjutnya setelah Undang-Undang Nomor 3 Tahun 1971 ini diganti dengan Undang-Undang Nomor 31 Tahun 1999 Tentang Pemberantasan Tindak Pidana Korupsi sebagaimana telah diubah dengan Undang-Undang Nomor 20 Tahun 2001 Tentang Perubahan Atas Undang-Undang Nomor 31 Tahun 1999 Tentang Pemberantasan Tindak Pidana Korupsi pidana tambahan uang pengganti juga diatur dengan rumusan serupa, yaitu dalam Pasal 18 Ayat (1) huruf b.

Pasal 18:

(1) Selain pidana tambahan sebagaimana dimaksud dalam Kitab UndangUndang Hukum Pidana, sebagai pidana tambahan adalah:

a. Perampasan barang bergerak yang berwujud atau tidak berwujud atau barang tidak bergerak yang digunakan untuk atau yang diperoleh dari tindak pidana korupsi, termasuk perusahaan milik terpidana dimana tindak pidana korupsi dilakukan, begitu pula barang yang menggantikan barang-barang tersebut;

b. Pembayaran uang pengganti yang jumlahnya sebanyak-banyaknya atau sama dengan harta yang diperoleh dari tindak pidana korupsi;

c. Penutupan seluruh atau sebagian perusahaan untuk waktu paling lama 1 (satu) tahun;

d. Pencabutan seluruh atau sebagian hak-hak tertentu atau penghapusan seluruh atau sebagian keuntungan tertentu, yang telah atau dapat diberikan oleh Pemerintah kepada terpidana.

(2) Jika terpidana tidak membayar uang pengganti sebagaimana dimaksud dalam ayat (1) huruf b paling lama dalam jangka waktu 1 (satu) bulan sesudah putusan pengadilan yang telah memperoleh kekuatan hukum tetap, maka harta bendanya dapat disita oleh Jaksa dan dilelang untuk menutupi uang pengganti tersebut.

(3) Dalam hal terpidana tidak mempunyai harta benda yang mencukupi untuk membayar uang pengganti sebagaimana dimaksud dalam ayat (1) huruf b, maka dipidana dengan pidana penjara yang lamanya tidak melebihi ancaman maksimum dari pidana pokoknya sesuai dengan ketentuan dalam Undang-Undang ini dan lamanya pidana tersebut sudah ditentukan dalam putusan pengadilan.

Undang-Undang memberikan penekanan khusus mengenai besaran uang pengganti tersebut yakni sebanyak-banyaknya sama dengan harta benda yang diperoleh dari tindak pidana korupsi. 
Secara yuridis hal ini harus diartikan kerugian yang dapat dibebankan kepada terpidana adalah kerugian negara yang besarnya nyata dan pasti jumlahnya sebagai akibat perbuatan melawan hukum baik sengaja maupun lalai yang dilakukan oleh terdakwa. Dengan demikian yang memegang peranan penting untuk hal tersebut adalah teknis penemuan kerugian keuangan negara yakni harus ditemukan berdasarkan hasil temuan instansi yang berwenang atau akuntan publik yang ditunjuk melalui tata cara/prosedur audit yang benar. ${ }^{7}$

Apabila pengadilan telah menjatuhkan putusan mengenai pembayaran uang pengganti sebagaimana dimaksud dalam Pasal 18 Ayat (1) huruf b, maka terpidana diberi waktu untuk membayar uang pengganti yakni paling lamat 1 (satu) bulan sesudah putusan pengadilan yang telah memperoleh kekuatan hukum tetap sebagaimana ditentukan dalam Pasal 18 Ayat (2) Undang-Undang Nomor 31 Tahun 1999 sebagaimana telah diubah dengan Undang-Undang Nomor 20 Tahun 2001 Tentang Perubahan Atas Undang-Undang Nomor 31 Tahun 1999 Tentang Pemberantasan Tindak Pidana Korupsi.

Bilamana batas waktu yang ditetapkan sudah terlewati dan ternyata terpidana tidak melaksanakan pembayaran uang pengganti, maka harta bendanya dapat disita oleh Jaksa dan dilelang untuk menutupi uang pengganti tersebut. Selanjutnya dalam Pasal 18 Ayat (3) dijelaskan apabila terpidana tidak mempunyai harta benda yang mencukupi untuk membayar uang pengganti sebagaimana dimaksud dalam Pasal 18 Ayat (1) huruf b, maka dipidana dengan pidana penjara yang lamanya tidak melebihi ancaman pidana maksimum dari pidana pokoknya sesuai dengan ketentuan dalam Undang-Undang ini dan lamanya pidana tersebut sudah ditentukan dalam putusan pengadilan.

Kendala dalam penjatuhan pembayaran uang pengganti dalam rangka penyelesaian keuangan negara pernah diungkapkan oleh Ramelan adalah:

1. Kasus korupsi dapat diungkapkan setelah berjalan dalam waktu yang lama sehingga sulit untuk menelusuri uang hasil kekayaan yang diperoleh dari korupsi.

2. Dengan berbagai upaya pelaku korupsi telah menghabiskan uang hasil korupsi atau mempergunakan/mengalihkan dalam bentuk lain termasuk mengatasnamakan nama orang lain yang sulit terjangkau hukum.

3. Dalam pembayaran pidana uang pengganti, si terpidana banyak yang tidak sanggup membayar.

4. Dasarnya pihak ketiga yang menggugat pemerintah atas barang bukti yang disita dalam rangka pemenuhan pembayaran uang pengganti ${ }^{8}$

Tujuan adanya pidana uang pengganti adalah memidana seberat mungkin para koruptor agar mereka jera dan untuk menakuti orang lain agar tidak melakukan korupsi. Tujuan lainnya adalah mengembalikan uang negara yang melayang akibat suatu perbuatan korupsi. Pemikiran ini sejalan dengan definisi tindak pidana korupsi. Menurut Undang-Undang, salah satu unsur tindak pidana korupsi adanya tindakan yang merugikan negara. Dengan adanya unsur ini, maka setiap terjadi suatu perbuatan korupsi pasti akan menimbulkan kerugian pada keuangan negara. Merupakan suatu hal yang wajar apabila kemudian pemerintah menetapkan suatu kebijakan yang

7 Adly, "Pidana Denda dan Uang Pengganti Terhadap Terpidana Dalam Tindak Pidana Korupsi (Studi Komparatif Hukum Indonesia dan Malaysia)”, hlm. 161.

8 Adly, "Pidana Denda dan Uang Pengganti Terhadap Terpidana Dalam Tindak Pidana Korupsi (Studi Komparatif Hukum Indonesia dan Malaysia)", hlm. 176 
tertuang dalam Undang-Undang untuk mengupayakan kembalinya uang negara yang hilang akibat tindak pidana korupsi.

Pasal 34 huruf c Undang-Undang Nomor 3 Tahun 1971 dan Pasal 18 Ayat (1) huruf $b$ hanya menetapkan rumusan sederhana mengenai besarnya uang pengganti yaitu sebanyak-banyaknya sama dengan harta yang diperoleh dari tindak pidana korupsi. Dapat ditafsirkan besarnya uang pengganti dapat dihitung berdasarkan nilai harta si terdakwa yang diperoleh dari tindak pidana korupsi yang didakwakan. Maka untuk menentukan besarnya uang pengganti, pertama-tama Hakim harus secara cermat memilah-milah bagian mana dari keseluruhan harta terdakwa yang berasal dari tindak pidana korupsi yang didakwakan kepadanya dan mana yang bukan. Setelah dilakukan penilaian, Hakim kemudian baru dapat melakukan perhitungan berapa besaran uang pengganti yang akan dibebankan. Dengan konsep ini Hakim pasti akan menemui kesulitan dalam menentukan besaran uang pengganti.

Pertama, Hakim akan sulit memilah-milah mana aset yang berasal dari tindak pidana korupsi dan mana yang bukan, karena perkembangannya kompleksitas suatu tindak pidana korupsi semakin meningkat. Selain itu untuk melakukan hal ini jelas butuh keahlian khusus serta data dan informasi yang lengkap. Apalagi jika harta yang akan dihitung berada diluar negeri sehingga membutuhkan birokrasi diplomatik yang pasti sangat rumit dan memakan waktu. Kedua, perhitungan besaran uang pengganti akan sulit dilakukan apabila aset terdakwa yang akan dinilai ternyata telah dikonfersikan dalam bentuk aset yang bedasarkan sifatnya mempunyai nilai fluktuatif, yang nilainya terus berubah. ${ }^{9}$

Dalam praktiknya, besaran uang pengganti dalam perkara korupsi yang dilakukan secara bersama-sama (penyertaan) ditetapkan berdasarkan dua model pembebanan, yaitu:

\section{Tanggung renteng}

Dalam model pembebanan secara tanggung renteng setiap terdakwa wajib memenuhi hukuman tersebut, dan sesuai konsep keperdataan apabila salah satu terdakwa telah melunasi sejumlah uang pengganti maka kewajiban terdakwa lain gugur secara otomatis

\section{Proporsional}

Beban uang pengganti dibebankan secara definitif oleh majelis Hakim kepada masing-masing terdakwa sesuai dengan kontribusinya.

Meskipun demikian, dalam penuntutan, Jaksa Agung telah menginstruksikan kepada penuntut umum untuk hanya menerapkan model pembebanan secara proporsional saja agar memberikan kepastian hukum dan menghindari kesulitan dalam eksekusi sebagaimana diatur dalam Surat Edaran Jaksa Agung (SEJA) No. B28/A/Ft.l/05/2009 trntang Petunjuk Kepada Jaksa Penuntut Umum Dalam Membuat Surat Tuntutan.

SEJA tersebut menyebutkan bahwa besaran uang pengganti yang dibebankan kepada masing-masing terdakwa harus disebutkan secara jelas dan pasti dalam amar tuntutan dan tidak boleh disebutkan dalam tanggung renteng. Jika harta hasil korupsi tidak diketahui secara pasti jumlahnya, maka besaran uang pengganti kepada masing-

\footnotetext{
9 Wawan, Uang Pengganti Sebagai Pidana Tambahan, https://wawansimbeling.blogspot.com/2016/05/uang-pengganti-sebagai-pidana tambahan.html, diakses 122019 / 5 /.
} 
masing terdakwa ditentukan dengan berpedoman kepada kualifikasi tutut serta sebagaimana diatur dalam Pasal 55 Ayat (1) Ke-1 KUHP.

Pidana tambahan pembayaran uang pengganti yang diatur dalam Pasal 18, dan penjelasan umum merumuskan "Undang-Undang ini memuat juga pidana penjara bagi pelaku tindak pidana korupsi yang tidak dapat membayar pidana tambahan berupa uang pengganti kerugian negara". Kenyataannya pelaksanaan suatu putusan pengadilan terhadap uang pengganti nyatanya tidak sedikit yang mengalami permasalahan, dikarenakan para terpidana lebih memilih dipidana penjara daripada membayar uang pengganti dengan alasan harta bendanya tidak ada lagi

Dari putusan pengadilan diatas dapat dilihat bahwa selain terdapat ketidakseimbangan antara besaran uang pengganti dengan pidana penjara pengganti. Dimana besaran uang pengganti yang jumlahnya mencapai ratusan juta hingga miliaran rupiah hanya diganti dengan pidana penjara subsider yang sangat singkat. Selain itu, dari putusan pengadilan di atas juga terdapat disparitas yang mencolok antara pidana penjara subsider yang satu dengan yang lainnya. Hal ini terjadi dikarenakan dalam Pasal 18 ayat (3) Undang-Undang Tindak Pidana Korupsi hanya terdapat aturan yaitu pidana penjara pengganti tidak melebihi ancaman pidana pokok. Jadi tidak ada pola atau aturan tersendiri yang dapat dijadikan patokan dalam menjatuhkan pidana penjara pengganti itu sendiri.

Ketiadaan acuan dalam merumuskan pidana penjara pengganti dalam hal uang pengganti tidak dibayar dalam jangka waktu tertentu telah menimbulkan disparitas dalam penjatuhan lamanya pidana penjara pengganti. Disparitas ini memperlihatkan bahwa penjatuhan uang pengganti dalam jumlah besar tidak serta merta diikuti dengan pidana penjara pengganti dalam waktu yang lama atau sepadan dengan nilai uang pengganti, begitu pula sebaliknya. Merujuk pada uraian diatas dapat dilihat bahwa sebab utama kemandekan eksekusi pembayaran uang pengganti pada kenyataannya disebabkan oleh faktor kebijakan, disamping komitmen penegak hukum. Untuk mengoptimalkan pembayaran ang pengganti tersebut diperlukan perubahan dan/atau penyempurnaan kebijakan penanganan perkara korupsi.

Mengenai pidana penjara pengganti, Penulis mengusulkan agar pidana penjara pengganti ditetapkan sesuai range kelasnya, dimana semakin besar uang pengganti, maka semakin lama pidana penjara penjara penggantinya.

\begin{tabular}{ccc}
\hline No & Range Kelas Uang Pengganti & $\begin{array}{c}\text { Usula Pidana Penjara } \\
\text { Pengganti }\end{array}$ \\
\hline 1 & $<100$ juta & 2 Tahun \\
\hline 2 & 100 Juta - 500 Juta & 3 Tahun - 5 Tahun \\
\hline 3 & 500 Juta - 1 Miliar & 5 Tahun - 10 Tahun \\
\hline 4 & 1 Miliar - 5 Miliar & 10 Tahun - 15 Tahun \\
\hline 5 & $>5$ Miliar & $>15$ Tahun \\
\hline
\end{tabular}

\section{Cara Pengembalian Kerugian Negara Melalui Pembayaran Uang Pengganti} Dengan Mengacu Pada Putusan Hakim Pengadian Tindak Pidana Korupsi.

“Tindak pidana korupsi di Indonesia yang terjadi secara sistematik dan meluas tidak hanya merugikan keuangan negara tetapi juga telah melanggar hak-hak sosial 
dan ekonomi masyarakat."10 Hal ini artinya tindak pidana korupsi sudah merupakan pelanggaran terhadap hak-hak asasi manusia, sebab praktik-praktik korupsi tersebut sudah sangat jelas merugikan kepentingan ekonomi dan sosial masyarakat, baik itu secara individu maupun secara kelompok.

Berdasarkan Pasal 18 Ayat (2) Undang-Undang Nomor 31 Tahun 1999 Tentang Pemberantasan Tindak Pidana Korupsi sebagaimana telah diubah dengan UndangUndang Nomor 20 Tahun 2001 Tentang Perubahan Atas Undang-Undang Nomor 31 Tahun 1999 Tentang Pemberantasan Tindak Korupsi, pengembalian kerugian negara melalui pembayaran uang pengganti harus dikembalikan oleh terdakwa dalam tempo 1 (satu) bulan sejak putusan pengadilan mempunyai kekuatan hukum tetap. Dalam praktiknya, pengembalian kerugian negara tersebut secara umum dapat dikatakan tidak berhasil, karena dalam perkara korupsi banyak terdakwa tidak memenuhi kewajibannya yang tertuang dalam putusan pengadilan tersebut. Dalam kondisi yang demikian menjadi kewajiban Jaksa untuk melakukan eksekusi uang pengganti dalam rangka pengembalian kerugian keuangan negara dalam tindak pidana korupsi, menunjukkan bahwa peran Jaksa sebagai ujung tombak dalam upaya pengembalian keuangan negara sangat besar. Untuk mencapai upaya pengembalian keuangan negara dari terpidana, maka Jaksa dapat melakukan penyitaan harta terpidana dan selanjutnya dilakukan pelelangan.

Dalam perkara korupsi sebagai mana diatur dalam Undang-Undang Nomor 31 Tahun 1999 Tentang Pemberantasan Tindak Pidana Korupsi sebagaimana telah diubah dengan Undang-Undang Nomor 20 Tahun 2001 Tentang Perubahan Atas Undang-Undang Nomor 31 Tahun 1999 Tentang Pemberantasan Tindak Pidana Korupsi diatur mengenai pengembalian aset hasil tindak pidana korupsi melalui jalur keperdataan berupa gugatan perdata maupun jalur kepidanaan.

UU PTPK kemungkinan dapat dilakukan perampasan terhadap aset hasil korupsi atau sarana korupsi dengan jalur tuntutan pidana jika jaksa penuntut umum dapat membuktikan kesalahan terdakwa yang telah melakukan tindak pidana korupsi tersebut dan aset-aset yang telah disita dalam perkara dimaksud sebagai hasil kejahatan tindak pidana korupsi. Dalam membuktikan kesalahan terdakwa di persidangan sering kali penuntut umum mengalami kesulitan dikarenakan modus kejahatan korupsi yang ditanganinya tersebut menggunakan cara-cara yang canggih ditambah lagi dengan tingginya standar pembuktian yang harus dipenuhi (beyond reasonable doubt). ${ }^{11}$

Apabila dirincikan perampasan aset yang melalui proses tuntutan pidana dilakukan dengan proses persidangan dimana hakim juga dapat menjatuhkan pidana tambahan. Pidana tambahan yang dijatuhkan hakim berkolerasi dengan pengembalian kerugian negara, dapat berupa:

a. Perampasan barang bergerak yang berwujud atau tidak berwujud atau barang yang tidak bergerak yang digunakan untuk atau yang diperoleh dari tindak pidana korupsi, termasuk perusahaan milik terpidana dimana tindak pidana korupsi dilakukan, begitu pula barang yang menggantikan barang-barang tersebut. (Pasal 18 Ayat (1) huruf a UU PTPK)

10 Penjelasan Undang-Undang Nomor 20 Tahun 2001 Tentang Perubahan Undang-Undang Nomor 31 Tahun 1999 Tentang Pemberantasan Tindak Pidana Korupsi.

11 Muhammad Yusuf, Merampas Aset Koruptor Solusi Pemberantasan Korupsi di Indonesia, (Jakarta: Kompas Media Nusantara, 2013), hlm. 162. 
b. Pembayaran uang pengganti yang jumlahnya sebanyak-banyaknya sama dengan harta yang diperoleh dari tindak pidana korupsi. Jika terpidana tidak membayar uang pengganti sebagaimana dimaksud dalam Ayat (1) huruf b paling lama dalam waktu satu bulan sesudah putusan yang telah memiliki kekuatan hukum tetap, maka harta bendanya dapat disita oleh jaksa dan dilelang untuk menutupi uang pengganti tersebut. Dalam hal terpidana tidak mempuyai harta benda yang mencukupi untuk membayar uang pengganti sebagaimana dimaksud dalam Ayat (1) huruf $b$, maka dipidana dengan pidana penjara yang lamanya tidak melebihi ancaman maksimum dari pidana pokoknya sesuai dengan ketentuan undangundang ini lamanya pidana tersebut sudah ditentukan dalam putusan pengadilan. (Pasal 18 Ayat (1) huruf b, ayat (2), (3) UU PTPK).

c. Masih berkenaan dengan perampasan aset melaui jalur tuntutan pidana UU PTPK juga memberikan jalan keluar terhadap perampasan terhadap harta benda hasil tindak pidana korupsi yang perkara pidananya tidak dapat dilanjutkan proses hukumnya karena sang terdakwa meninggal dunia setelah proses pembuktian dan dari pemeriksaan alat bukti dipersidangan terdapat bukti yang cukup kuat bahwa yang bersangkutan telah melakukan tindak pidana korupsi, maka hakim atas tuntutan penuntut umum menetapkan perampasan barang-barang yang telah disita dan penetapan perampasan sebagaimana dimaksud dalam Ayat (5) tidak dapat dimohonkan upaya banding. Ketentuan dimaksud ada dalam Pasal 38 Ayat (5) dan (6)..$^{12}$

Pengaturan mengenai perampasan aset belum diatur secara khusus dalam peraturan perudang-undangan di Indonesia, dan ketentuan yang sudah ada, yaitu Undang-Undang Pemberantasan Tindak Pidana Korupsi juga mempunyai kelemahan, yakni apabila dengan jalur tuntutan pidana upaya untuk merampas aset hasil tindak pidana hanya dapat dilaksanakan jika pelaku kejahatan telah dinyatakan terbukti secara sah bersalah dan meyakinkan bersalah telah melakukan tindak pidana oleh hakim di pengadilan.

Mekanisme yang diterapkan sering kali mengalami kesulitan akibat adanya kendala yang mengakibatkan pelaku kejahatan tidak bisa menjalani proses pemeriksaan di sidang pengadilan, juga dapat terjadi kemungkinan bahwa tidak dapat diterapkan karena tidak ditemukan bukti yang cukup untuk mengajukan tuntutan ke pengadilan dan sebagainya. Aset yang dimaksudkan juga dapat dengan mudah dialihkan atau bahkan dibawa lari ke luar negeri.

Kemudian pengembalian aset tindak pidana korupsi melalui jalur keperdataan dapat dilakukan melalui aspek-aspek sebagai berikut:

a. Ketentuan lebih lanjut tentang perampasan aset hasil tindak pidana korupsi melalui jalur perdata dapat dilihat dari ketentuan Pasal 31 UU PTPK yang pada pokoknya menyebutkan dalam hal penyidik menemukan dan berpendapat bahwa satu atau lebih unsur tindak pidana korupsi tidak terdapat cukup bukti, sedangkan secara nyata telah ada kerugian keuangan negara, maka penyidik segera menyerahkan berkas perkara hasil penyidikan tersebut kepada Jaksa Pengacara Negara untuk dilakukan gugatan perdata atau diserahkan kepada instansi yang dirugikan untuk mengajukan gugatan. Sedangkan pada Ayat (2) dari pasal yang sama memberikan alasan untuk diajukannya gugatan perdata terhadap perkara tindak pidana korupsi yang diputus bebas.

12 Muhammad Yusuf, Merampas Aset Koruptor Solusi Pemberantasan Korupsi di Indonesia „, hlm. 163. 
b. Selanjutnya Pasal 33 UU PTPK juga memberikan dasar hukum tentang perampasan aset hasil tindak pidana korupsi melalui jalur gugatan perdata yang tersangkanya meninggal dunia saat perkaranya sedang disidik dan dari penyidikan tersebut telah ditemukan adanya kerugian keuangan negara. Gugatan perdata tersebut akan diajukan terhadap ahli warisnya,

c. Ketentuan lain yang memungkinkan dilakukannya perampasan aset hasil tindak pidana korupsi melalui jalur gugatan perdata dapat dilihat dalam Pasal 34 UU PTPK yang mengatur bahwa dalam hal terdakwa meninggal dunia pada saat dilakukan pemeriksaan di sidang pengadilan, sedangkan secara nyata telah ada kerugian negara, maka penuntut umum segera menyerahkan salinan berkas acara sidang tersebut kepada Jaksa Pengacara Negara atau diserahkan kepada instansi yang dirugikan untuk dilakukan gugatan perdata terhadap ahli warisnya. Ketentuan-ketentuan tersebut pada pokoknya mengatur tata cara perampasan aset dan hasil korupsi yang perkara pidananya tidak dapat dilanjutkan proses hukumnya.

d. Ketentuan Pasal 38C UU PTPK mengatur tentang dimungkinkannya diajukan gugatan terhadap aset hasil tindak pidana korupsi yang perkara pidananya dapat diproses dan diputus oleh pengadilan dengan kekuatan hukum tetap, namun ternyata masih terdapat aset atau harta benda milik terpidana yang diduga atau patut diduga juga berasal dari tindak pidana korupsi yang belum dikenakan perampasan untuk negara sebagaimana dimaksud dalam Pasal 38C Ayat (2) UU PTPK, maka negara dapat melakukan gugatan perdata terhadap terpidana dan atau ahli warisnya. ${ }^{13}$

Menurut Fatwa Mahkamah Agung RI Nomor: 37/T4/88/66/Pid tanggal 12 Januari 1988 penerapan eksekusi pembayaran uang pengganti adalah:

1. Barang-barang terpidana yang masih ada disita dan kemudian dijual dengan cara melelangnya bertujuan untuk memenuhi kewajiban pidana pembayaran uang pengganti;

2. Penyitaan hendaknya dikecualikan atas barang-barang yang dipakai sebagai penyanggah mencari nafkah terpidana dan keluarganya

3. Penyitaan hendaknya menghindari kesalahan penyitaan terhadap barang yang bukan milik terpidana agar jangan sampai terjadi perlawanan dari pihak ketiga yang merasa dirugikan. ${ }^{14}$

Keprofesionalan jaksa merupakan ujung tombak tegaknya eksekusi pidana. Hal tersebut membawa dampak terhadap profesi seorang jaksa eksekutor yang menjalankan tugas dan wewenang selaku pelaksana putusan pidana. Berdasarkan peraturan di Kejaksaan secara internal yaitu dalam Keputusan Jaksa Agung (Kepja) Nomor KEP-518/J.A/11/2011. Dalam Peraturan itu dirumuskan bahwa salah satu tahapan eksekusi uang pengganti adalah menanyakan sanggup tidaknya membayar uang pengganti. Kalimat "menanyakan sanggup tidaknya terpidana membayar uang pengganti" tersebut jelas menyatakan bahwa terpidana diberi pilihan sehingga dapat memilih antara menyatakan sanggup membayar uang pengganti atau tidak. Keadaan ini pada akhirnya dimanfaatkan oleh para terpidana karena didukung dengan keadaan dan keterbatasan penanganan perkara korupsi yang dengan mudahnya mengaku tidak

13 Muhammad Yusuf, Merampas Aset Koruptor Solusi Pemberantasan Korupsi di Indonesia, hlm. 166.

14 Fatwa Mahkamah Agung RI Nomor: 37/T4/88/66/Pid Tanggal 12 Januari 1988 Fatwa Mengenai Eksekusi Pembayaran Uang Pengganti (Pasal 34 sub c UU No. 3 Tahun 1971) 
lagi mempunyai harta untuk membayar dan melunasi uang pengganti, dan "memilih" pidana penjara pengganti yang lebih menguntungkan baginya.

Guna membenahi persoalan itu, sebaiknya jaksa berperan aktif untuk menelusuri aset terpidana sehingga harta benda yang disita cukup untuk membayar uang pengganti. Pidana tambahan pembayaran uang pengganti baru bisa dieksekusi jaksa apabila putusan hakim telah memiliki kekuatan hukum tetap. Ada baiknya perampasan/penyitaan barang-barang milik terdakwa dilakukan pada saat penyidikan, guna untuk menghindari pengalihan aset terhadap harta benda milik terdakwa mengingat proses persidangan membutuhkan waktu yang lama sehingga ditakutkan terdakwa tindak pidana korupsi menghabiskam hasil korupsi dengan berbagai cara maupun mengalihkannya pada pihak ketiga atau dalam bentuk lain.

Mengenai pembayaran uang pengganti sebagaimana diatur dalam Pasal 18 Ayat (1) huruf b, teknis pembayaran uang pengganti tidak mempunyai peraturan yang konkrit dalam undang-undang tentang cara pembayarannya harus secara tunai (cash) atau dibolehkan secara mencicil.

Mekanisme pembayaran uang pengganti yang demikian dapat dilihat dari dua sisi, yaitu dalam Pasal 18 Ayat (2) mengenai batasan waktu dalam pembayaran uang pengganti, dan yang kedua adanya Surat Edaran Jaksa Agung Tahun 2015 yang membenarkan pembayaran yang pengganti yang secara diangsur sampai lunas. Namun sejauh mana Surat Edaran itu mengikat sedangkan konsep dan semangat didalamnya bertentangan dengan Undang-Undang Tindak Pidana Korupsi yang memberi batasan penyelesaian pembayaran uang pengganti agar kerugian negara secepatnya terpulihkan. ${ }^{15}$

Namun faktanya terpidana pada umumnya tidak sanggup membayar sampai melunasi uang pengganti, karena tidak mempunyai harta benda yang mencukupi untuk melunasi uang pengganti tersebut, maka konsekuensi hukumnya melaksanakan serta menjalankan hukuman subsider yaitu pidana penjara dan telah disebutkan dalam amar putusan pengadilan. Namun dampak dari dipraktikkannya mekanisme pembayaran secara mencicil tersebut, akan membuat sifat kepastian dari masa pidana penjara yang menjadi subsider dari pidana uang pengganti menjadi tidak pasti, karena ketidakpastian lunas tidaknya uang pengganti tersebut, belum lagi dalam hal dilunasi dalam persentase tertentu dari jumlah total uang pengganti, maka bagaimana konsekuensi hukum terhadap terpidana perkara tindak pidana korupsi tersebut, apakah terpidana tetap menjalani pidana penjara pengganti sebagaimana ditetapkan dalam amar putusan ataukah ada pengurangan masa tahanan dikarenakan telah membayar uang pengganti sebagian dari total jumlah uang pengganti. Disamping itu mekanisme pembayaran uang pengganti secara mencicil ternyata tidak mendorong terpidana kasus korupsi untuk melunasi uang pengganti tersebut.

Adapun mekanisme pembayaran pidana uang pengganti yang seharusnya dilakukan, berdasarkan keputusan Jaksa Agung Nomor: Kep-518/J.A/11/2001 tanggal 1 November 2001, dilakukan dengan tahapan:

1. Dibuatkan surat penagihan (D-1) dengan perihal penagihan uang pengganti kepada terpidana untuk menghadap jaksa eksekutor di kantor kejaksaan setempat. Kemudian terpidana dipanggil dan menghadap jaksa eksekutor

15 Intan Munirah, Mohd. Din, Efendi, "Pembayaran Pidana Uang Pengganti Dalam Perkara Korupsi”, Kanun Jurnal Ilmu Hukum, 19, 2, (2017), hlm. 12. 
ditanya tentang kesanggupan membayar uang pengganti yang telah dijatuhkan oleh pengadilan yang telah berkekuatan hukum tetap.

2. Pada tahap ini dibuatkan surat pernyataan (D-2) yang isinya sanggup atau tidak sanggup membayar uang pengganti. Apabila tidak sanggup membayar disertai dengan surat tidak mampu dari kelurahan/ kepala desa.

3. Lalu pada saat membayar uang pengganti, maka dibuatkan tanda terima pembayaran (D-3), uang yang telah diterima dari terpidana dan ditandatangani oleh Kasi Pidsus atas nama Kepala Kejaksaan Negeri.

4. Selanjutnya setelah diterima uang pengganti dari terpidana maka Kepala Kejaksaan Negeri/Tinggi setempat membuat surat perintah (D-4) yang memerintahkan jaksa eksekutor/ Kasi Pidsus/ Kasubsu Penuntutan Pidsus untuk menyerahkan uang pengganti atas nama terpidana yang bersangkutan kepada Kasubagbin Kejaksaan setempat.

5. Bendahara Khusus/Penerima setelah menerima uang pengganti dalam waktu 1x24 jam harus menyetorkan uang pengganti dengan blangko Surat Setoran Penerima Negara Bukan Pajak dengan Mata Penerimaan Anggaran (MAP) 424573 melalui bank.

6. Berdasarkan surat JAM BIN Nomor: 423614 berlaku sejak Januari 2008. Apabila terpidana tidak membayar uang pengganti maka harus ada bukti bahwa terpidana telah menjalani pidana pengganti. Hal ini harus dibuktikan dengan berita acara pelaksanaan hukuman pengganti (BA-8). ${ }^{16}$

Berdasarkan Undang-Undang Nomor 20 Tahun 2001 Tentang Perubahan Atas Undang-Undang Nomor 31 Tahun 1999 Tentang Pemberantasan Tindak Pidana Korupsi, pidana tabahan pembayaran uang pengganti merupakan tujuan dalam rangka meyelamatkan kekayaan dan/atau keuangan negara yang telah diambil oleh pelaku korupsi juga untuk menghukum seberat-beratnya pelaku korupsi sesuai hukum yang berlaku. Kenyataannya pelaksanaan putusan pengadilan terhadap uang pengganti tidak sedikit mengalami permasalahan dikarenakan terpidana lebih memilih pidana penjara daripada memilih membayar uang pengganti dengan alasan kalau harta bendanya sudah tidak ada lagi.

Hal itu lebih dipilih oleh terpidana dibandingkan kehilangan harta bendanya yang mempunyai nilai ekonomi yang mempuyai ekspektasi untuk peningkatan nilainya atau untuk diinvestasikan. Dalam hal ini bisa kita lihat sejauh mana pidana penjara dan pidana uang pengganti mencapai tujuan pidana dalam konteks teori tujuan pemidanaan relatif. Didominasinya pelaksanaan pidana subsider dibandingkan pidana uang pengganti, bila kita lihat dari sisi yang berbeda seolah-olah keberadaan pidana subsider bagi terpidana korupsi yag tidak membayar atau tidak lunas membayar uang pengganti sebagai alternatif lain diberi hukuman pidana tambahannya berupa pidana pejara akan memperlemah undang-undang ini mengenai hal mencapai pengembalian keuangan negara dengan waktu yang singkat, atau kadar pidana subsider penjara harus diperberat. Perumusan peraturan perundang-undangan yang rumit dan tidak jelas akan memunculkan ketidakpastian hukum dan menghalangi keberhasilan penanggulan suatu tindak pidana. ${ }^{17}$ Gutav Radbruch dalam Usman, ada tiga nilai yang

16 Intan Munirah, Mohd. Din, Efendi, "Pembayaran Pidana Uang Pengganti Dalam Perkara Korupsi", hlm 15.

17 Hafrida, "Analisis Yuridis Terhadap Gratifikasi Dan Suap Sebagai Tindak Pidana Korupsi Menurut Undang-Undang Nomor 31 Tahun 1999 Jo. Undang-Undang Nomor 20 Tahun 2001 Tentang Pemberantasan Tindak Pidana Korupsi", Inovatif, Jurnal Ilmu Hukum, Volume 6 Nomor 7, Tahun 2013, hlm. 8. 
diperlukan untuk sampai pada pengertian hukum, pertama, ialah keadilan dalam arti kesamaan hak untuk setiap orang di depan pengadilan. Kedua, adalah tujuan keadilan atau finalitas, yaitu sesuatu yang menimbulkan kebaikan atau manfaat. Ketiga, adalah nilai kepastian hukum atau legalitas. ${ }^{18}$ Perturan perundang-undangan sebagai jaminan legalitas seharusnya dirumuskan dengan jelas demi menjaga kepastian hukumnya.

\section{Simpulan}

Berdasarkan pembahasan yang diuraikan oleh Penulis maka dapat disimpulkan sebagai berikut: Membayar uang pengganti adalah cara ganti rugi terhadap negara yang diakibatkan oleh pelaku tindak pidana korupsi. Pengaturan mengenai uang pengganti itu sendiri diatur dalam Undang-Undang Nomor 31 Tahun 1999 Tentang Pemberantasan Tindak Pidana Korupsi sebagaimana telah diubah dengan UndangUndang Nomor 20 Tahun 2001 Tentang Perubahan Atas Undang-Undang Nomor 31 Tahun 1999 Tentang Pemberantasan Tindak Pidana Korupsi. Akan tetapi, pengaturan tentang pembayaran uang pengganti itu sendiri masih kurang jelas. Berdasarkan kasus yang Penulis uraikan, yakni Putusan Pengadilan Perkara Tindak Pidana Korupsi di Pengadilan Negeri Jambi Tahun 2018 terdapat ketidakseimbangan antara besaran uang pengganti dengan pidana penjara penggantinya. Selain itu, dapat dilihat juga adanya disparitas yang cukup mencolok antara pidana penjara pengganti yang satu dengan yang lainnya. Batas waktu membayar uang pengganti telah diatur dalam Pasal 18 Ayat (2) yakni selama 1 (satu) bulan. Mekanisme membayar uang pengganti diatur dalam Keputusan Jaksa Agung Nomor: Kep-518/J.A/11/2001 Tanggal 1 November 2001. Mengenai teknis pembayaran uang pengganti itu sendiri tidak mempunyai aturan konkrit dalam undang-undang tentang cara pembayarannya harus secara tunai atau dibolehkan secara mencicil. Dalam Surat Edaran Jaksa Agung Tahun 2015 dibenarkan pembayaran uang pengganti yang dibayar secara diangsur sampai lunas. Namun dampak dari dipraktikkannya mekanisme tersebut, akan membuat sifat kepastian dari masa pidana penjara yang menjadi subsider dari pidana uang pengganti menjadi tidak pasti, karena ketidakpastian lunas tidaknya uang penggati tersebut, dan bagaimana konsekuensi hukum terhadap terpidana yang membayar uang pengganti dalam persentase tertentu dari total jumlah uang pengganti.

\section{DAFTAR PUSTAKA}

\section{Dokumen Hukum}

Kitab Undang-Undang Hukum Pidana.

Republik Indonesia, Undang-Undang Tentang Hukum Acara Pidana. UU Nomor 8 Tahun 1981.

${ }^{18}$ Usman, Andi Najemi, Mediasi Penal di Indonesia, Keadilan, Kemanfaatan, dan Kepastian Hukumnya, Undang: Jurnal Hukum, Vol. 1 No. 1 (2018): 65-83, DOI: 10.22437/ujh.1.1.65-83. hlm. 70 . 
Republik Indonesia, Undang-Undang Tentang Perubahan atas Undang-Undang Nomor 31 Tahun 1999 Tentang Pemberantasan Tindak Pidana Korupsi. UU Nomor 20 Tahun 2001. LNRI Tahun 2001 Nomor 134, TLNRI Nomor 4150.

Republik Indonesia, Undang-Undang Tentang Komisi Pemberantasan Tindak Korupsi. UU Nomor 30 Tahun 2002. LNRI Tahun 2002 Nomor 137. TLNRI Nomor 4250.

Republik Indonesia, Undang-Undang Tentang Pengadilan Tindak Pidana Korupsi. UU Nomor 46 Tahun 2009. LNRI Tahun 2009 Nomor 155. TLNRI 5074.

Republik Indonesia, Undang-Undang Tentang Pengesahan United Nations Convention Againt Corruption, 2003 (Konvensi Perserikatan Bangsa-Bangsa Anti Korupsi, 2003). UU Nomor 7 Tahun 2006. LNRI Tahun 2006 Nomor 4620.

Republik Indonesia, Peraturan Mahkamah Agung Tentang Pidana Tambahan Uang Pengganti Dalam Tindak Pidana Korupsi.Perma Nomor 5 Tahun 2014. LNRI Tahun 2014. TLNRI Nomor 8.

\section{Buku}

Hamzah Ahmad dan Anando Santoso, Kamus Pintar Bahasa Indonesia, Fajar Mulia, Surabaya, 1996.

Jeremy Pope. Strategi Memberantas Korupsi Elemen Sistem Integritas Nasional. Jakarta: Penerbit Buku Yayasan Obor Indonesia, 2007.

Muhammad Yusuf. Merampas Aset Koruptor Solusi Pemberantasan Korupsi di Indonesia. Jakarta: Penerbit Buku Kompas Media Nusantara, 2013.

Adly, "Pidana Denda dan Uang Pengganti Terhadap Terpidana Dalam Tindak Pidana Korupsi (Studi Komparatif Hukum Indonesia dan Malaysia)" Disertasi, Universitas Jambi, Jambi, 2017.

\section{Jurnal/ Majalah Ilmiah}

Hafrida, "Analisis Penerapan Pasal 2 Undang-Undang Nomor 31 Tahun 1999 Jo Undang-Undang Nomor 20Tahun 2001 Tentang Tindak Pidana Korupsi Pada Perkara No. 01/Pid.B/Tpk/2012/Pn. Jbi.", Jurnal Ilmu Hukum, Vol. 6, No. 2, (2013).

Hafrida, "Analisis Yuridis Terhadap Gratifikasi Dan Suap Sebagai Tindak Pidana Korupsi Menurut Undang-Undang Nomor 31 Tahun 1999 Jo. Undang-Undang Nomor 20 Tahun 2001 Tentang Pemberantasan Tindak Pidana Korupsi", Inovatif, Jurnal Ilmu Hukum, Vol. 6, No. 7, Tahun 2013.

Usman, Andi Najemi, Mediasi Penal di Indonesia, Keadilan, Kemanfaatan, dan Kepastian Hukumnya, Undang: Jurnal Hukum, Vol. 1, No. 1 (2018): 65-83, DOI: $10.22437 /$ ujh.

Fontian Munzil et al., "Kesebandingan Pidana Uang Pengganti dan Pengganti Pidana Uang Pegganti Dalam Rangka Melindungi Hak Ekonomi Negara dan Kepastian Hukum", Jurnal Hukum Ius Quia Iustum, Vol. 22, No. 1, (2015). 
Intan Munirah, Mohd. Din, Efendi, "Pembayaran Pidana Uang Pengganti Dalam Perkara Korupsi”, Kanun Jurnal Ilmu Hukum, Vol. 19, No.2, (2017). 